\title{
Wireless Sensor Networks For Volcano Activity Monitoring: A Survey
}

\author{
Elisati Hulu ${ }^{1}$, Bambang Riyanto $\mathrm{T}^{2}$, Sri Widyantoro ${ }^{3}$ \\ ${ }^{1,2}$ School of Electrical Engineering and Informatics, Institut Teknologi Bandung, \\ ${ }^{3}$ Faculty of Mining and Petroleum Engineering, Institut Teknologi Bandung, \\ Email: ${ }^{1}$ elisatih@students.itb.ac.id, ${ }^{2}$ briyanto@1skk.ee.itb.ac.id, ${ }^{3}$ sriwidiyantoro@yahoo.com.sg
}

\begin{abstract}
Abstrak
Pemantauan gunung api merupakan salah satu bidang penerapan Wireless Sensor Network (WSN). WSN digunakan pertama kali untuk pemantauan gunung api di gunung Tungurahua, Ekuador Tengah pada tahun 2004. Selanjutnya diterapkan pada riset di gunung Reventador, Ekuador Utara dengan 16 sensor digunakan untuk menangkap sinyal seismik dan akustik. Pada kedua riset ini, desain jaringan dan algoritma dibangun untuk menangkap raw-data sinyal seismik dan akustik, dan mengirimnya ke base station. Seperti dua riset sebelumnya, proyek OASIS membangun WSN yang robust untuk memperoleh raw-data sebanyak-banyaknya dengan real time, kontinu dan kualitas sinyal yang high-fidelity. Berbeda dengan riset WSN untuk pemantauan gunung api sebelumnya, riset Rui Tan, dkk. dan Guojin Liu, dkk. mengembangkan WSN untuk pemantauan gunung api secara real time, in-situ dan long-lived tanpa transmisi raw-data ke base station. WSN dan algoritma didesain dengan membangun algoritma pemrosesan in-network untuk mendeteksi gempa vulkanik, menentukan onset time dari gelombang yang biasa muncul pada saat terjadi gempa.
\end{abstract}

Kata kunci: WSN, Volcano activity monitoring, Survey, Volcanic earthquake detection

\section{PENDAHULUAN}

Wireless Sensor Network (WSN) sudah semakin berkembang pesat dan luas. Perkembangan ini tidak terlepas dari perkembangan dari teknologi sensor, teknologi komunikasi dan teknologi digital. Pemantauan aktifitas gunung api merupakan salah satu bidang penerapan WSN, selain di bidang transportasi, perkebungan, gedung, dan lain sebagainya.

Penerapan WSN untuk pemantauan gunung api dilakukan pertama kali di gunung Tungurahua tahun 2004, dengan sensor akustik untuk memperoleh data infrasonik. WSN bersifat adhoc, tidak real time dan single-hop [1]. Pengembangan penerapan WSN dilanjutkan di gunung Reventandor, dengan 16 sensor membentuk jaringan multihop untuk memperoleh sinyal seismik dan akustik. Pada kedua pengembangan ini dibangun beberapa algoritma untuk mendeteksi kejadian vulkanik dan algoritma untuk transfer data ke base station yang efisien [2,3]. Proyek OASIS merupakan penerapan WSN yang lebih besar yaitu dengan mengintegrasikan jaringan sensor di bumi dengan observasi satelit bumi milik NASA untuk memantau gunung api St. Helens [4-7]. Berbagai pengembangan algoritma yang dilakukan, untuk membangun WSN yang robust, real time dan high-fidelity.

Implementasi WSN di [1,2,3] maupun di [4-7] berfokus pada pengembangan WSN yang dapat mengumpulkan raw-data yang high-resolution secara kontinu dan dalam waktu 
nyata. Berbeda dengan pengembangan sebelumnya, Rui Tan, dkk pada $[8,10]$, dan Guojin Liu, dkk pada [9], menerapkan WSN untuk pemantauan gunung api dengan mengembangkan algoritma untuk mendapatkan values (keputusan) langsung dari jaringan, in-situ, long-lived dan dalam waktu nyata. Values yang diperoleh langsung tersebut berupa keputusan deteksi gempa vulkanik, termasuk penentuan onset time-nya yang dilakukan secara in-network processing tanpa transmisi raw-data ke base station.

Dilakukan survei terhadap hampir semua pengembangan WSN untuk pemantauan aktifitas gunung api. Survei ini didasarkan pada riset yang ditulis dalam beberapa paper, mulai ketika WSN pertama kali diterapkan di gunung api, baik yang dilakukan dalam percobaan testbed di laboratorium, maupun percobaan yang dilakukan langsung di gunung api. Bagian selanjutnya dari makalah ini terdiri dari bagian 2 , tentang metodologi atau model dan teori, bagian ke-3 hasil dan pembahasan dan pada bagian ke-4 dikemukakan kesimpulan dari survei ini.

\section{METODE}

\subsection{Wireless Sensor Network (WSN)}

Wireless Sensor Network terdiri dari dua komponen utama yaitu node sensor yang memiliki fungsi penyimpanan (storage), pemrosesan dan komunikasi, dan sensor yang dapat mengukur atau sensing fenomena atau besaran fisis dari lingkungan dimana sensor tersebut ditempatkan.

Pada dasarnya WSN adalah merupakan jaringan dari node-node yang berdiri sendiri secara individual, yang memiliki kemampuan sensing atau pengukuran besaran fisis, menyimpan, memproses serta memiliki kemampuan komunikasi, dibangun dengan sedikit atau tanpa infrastruktur yang tetap, node-node tersebut bekerja sama untuk memantau area, situasi atau lingkungan tertentu.

Sekarang ini WSN telah dikembangkan pada beberapa lokasi, area atau lingkungan. Berdasarkan itu, WSN dapat diklasifikasikan dalam lima tipe [11] yaitu:

1. Terrestrial WSN, terdiri dari seratus atau ribuan node sensor yang disebar di tanah pada area tertentu, bersifat adhoc dan berkomunikasi dengan base station.

2. Underground WSN, sejumlah sensor yang disebar dalam gua, atau di pertambangan atau di bawah tanah untuk memantau kondisi di bawah tanah. Untuk berkomunikasi dengan base station biasanya ditempatkan sebuah sink node di atas permukaan tanah.

3. Underwater WSN, dimana sejumlah sensor ditempatkan di bawah air, seperti di lingkungan lautan. Sensor yang disebar hanya beberapa dan dilengkapi dengan kendaraan yang autonomous yang digunakan untuk mengeksplorasi atau mengambil data dari sensor-sensor tersebut.

4. Multimedia WSN, terdiri dari node sensor yang dilengkapi dengan peralatan kamera dan mikrofon. Sensor dapat menyimpan, memproses dan menerima data multimedia seperti video, audio dan image.

5. Mobile WSN, terdiri dari node sensor bergerak yang dapat berpindah dan berinteraksi dengan lingkungan fisik. Pergerakan tersebut dengan cara mengatur 
dan memposisikan ulang dirinya di jaringan dan untuk dapat melakukan pengukuran, pemrosesan dan berkomunikasi.

\subsection{Pemantauan Gunung Api}

Aktifitas gunung api pada umumnya bersifat lokal, karena kejadian letusan, kecuali letusan yang sangat besar, umumnya hanya berdampak beberapa kilometer dari sekitar gunung api. Ada gunung api yang jauh dari pemukiman penduduk, sehingga dampak aktifitas gunung api tidak terlalu terpengaruh kepada penduduk, tetapi ada juga gunung api yang dijadikan tempat pariwisata, berdekatan dengan area perkebunan atau lahan pertanian, atau pemukiman penduduk, seperti halnya umumnya gunung api di Indonesia [15].

Pemantauan gunung api memiliki fungsi utama yaitu menyediakan data ilmiah mendasar terkait dengan struktur dan dinamika gunung api dan serta merta hal-hal tersebut penting bagi menilai akan bahaya, prediksi letusan dan mitigasi risiko ketika gunung api bergejolak. Jadi pemantauan gunung api terdiri dari usaha sistematik untuk mengecek berbagai tipe dari data geologis, geokimia dan geofisik [16]. Semua data ini memberikan informasi terkait semua proses fisik dari aktifitas gunung api.

Memantau aktifitas gunung api, menurut ahli gunung api, memiliki tiga metode utama yaitu mengevaluasi tipe, magnitude dan lokasi dari gempa, mengamati dan menafsirkan naik turunnya permukaan tanah, dan mendeteksi perubahan terhadap aliran panas, air dan gas dari gunung api [17]. Karenanya pemantauan dapat dikategorikan berdasarkan tipe data pengukuran $[16,17]$ yaitu:

1. Pemantauan seismik adalah sebuah usaha sistematik untuk mengecek aktifitas seismik di gunung api. Aktifitas seismik dianggap indikator terbaik untuk memprediksi level dan evolusi aktifitas vulkanik. Pada setiap rekaman letusan gunung api biasanya didahului dengan perubahan pada aktifitas seismik di dalam atau di sekitar gunung api [18].

2. Pemantauan deformasi tanah, yaitu usaha yang dilakukan dengan mengamati perubahan tinggi vertikal atau jarak horizontal pada permukaan tanah gunung api, yang biasanya terjadi sebelum atau sesudah dan selama gempa atau letusan vulkanik.

3. Pemantauan gas bersama dengan temperatur juga biasa dilakukan pada gunung api.

Idealnya, pemantauan gunung api yang aktif atau yang berpotensi aktif dilakukan secara waktu-nyata atau mendekati waktu nyata (near real time) [19].

\subsection{WSN untuk Pemantauan Gunung Api}

Implementasi WSN untuk mempelajari aktifitas gunung api pertama kali dilakukan pada Juli 2004 di Tungurahua, sebuah gunung api aktif di Ekuador Tengah [1]. WSN digunakan untuk memonitor letusan gunung api dengan menggunakan sensor akustik berfrekuensi rendah. WSN masih bersifat adhoc, tidak real time dan single-hop. Data vulkanik berhasil diambil sebanyak $1.7 \mathrm{~GB}$, selama 54 jam dengan sekurang-kurangnya terdeteksi 9 kali ledakan besar. 
Pengembangan WSN di gunung Tungurahua untuk mengumpulkan sinyal infrasonik, yang ditransmisi ke base station melalui link wireless[1]. Untuk mengurangi keperluan akan komunikasi dikembangkan algoritma event-detector terdistribusi dan algoritma deteksi lokal yang berjalan di node sensor. Algoritma terdistribusi menggunakan proses pemilihan (decentralized voting) untuk mengukur korelasi sinyal antar node supaya hanya sinyal yang berkorelasi baik yang ditransmisi ke base station. Algoritma deteksi event lokal berjalan di node sensor dengan tujuan untuk memungkinkan implementasi pendekatan yang berbeda. Ada dua implementasi pendekatan yang dikembangkan yaitu detektor threshold-based dan detektor exponentially weighted moving average (EWMA)-based.

Melanjutkan riset yang sama dengan [1], implementasi WSN untuk memonitor gunung api dilakukan di gunung Reventandor, Ekuador Utara [2,3]. WSN disebar selama 19 hari dengan 16 sensor yang secara kontinu mengumpulkan sinyal seismik dan akustik dan menangkap 230 kejadian vulkanik, yaitu gempa bumi, erupsi, dan kejadian seismikakustik yang lain. Data yang terkumpul dikirim ke base station melalui jaringan multihop dan link radio jarak jauh ke observatorium.

Fokus utama pada implementasi WSN di gunung Reventador, Ekuador Utara [2,3] terkait kehandalan jaringan, akurasi event detection, performa transfer data, akurasi timing dan data fidelity. Node sensor membentuk jaringan multihop dengan routing tree yang simpulnya pada sebuah node gateway. Varian dari MintRoute digunakan sebagai algoritma routing, dan base station dapat mengajukan perintah ke setiap node, misalnya untuk menginstruksikan kepada node untuk segera mengirimkan pesan status, menghentikan atau memulai sampling data, dan mengatur beberapa parameter perangkat lunak yang digunakan. Perintah dari base station dikirimkan dengan menggunakan protokol Deluge.

Deteksi event dilakukan di setiap node dan sampel data disimpan di memori flash lokal dengan struktur buffer sirkular [2,3]. Dikembangkan detektor berbasis STA/LTA dengan menghitung 2 exponentially weighted moving average (EWMA), sehingga node dapat membedakan sinyal dengan amplitudo rendah dan amplitudo tinggi. Untuk mengumpulkan data digunakan protokol Fetch, sebuah protokol transfer yang handal, di mana base station yang berinisiatif meminta data dari setiap node sensor. Karena buffer yang terbatas dan untuk menjamin sampel data tidak tertimpa dengan sampel baru, base station mengajukan perintah kepada setiap node untuk menghentikan sampling.

Data yang dikumpulkan di base station berasal dari berbagai node sensor. Untuk mendapatkan analisis sinyal yang sangat baik akan sampel data yang terkumpul, memerlukan pewaktuan yang akurat dan sinkron. Pada implementasi ini $[2,3]$ digunakan protokol pewaktuan global Flooding Time Synchronization Protocol (FTSP) berbasis GPS untuk mendapatkan timestamp yang akurat dan sinkron. Setiap 10 detik setiap node mencatat waktu lokalnya dan memetakan dengan waktu global, kemudian mengirimkan informasi ini dalam pesan statusnya ke base station. Protokol ini bekerja baik pada saat eksperimen di laboratorium, tetapi mengalami kegagalan pada saat implementasi di lapangan. 
Implementasi WSN untuk memonitor gunung api dilakukan berikutnya pada proyek OASIS (Optimized Autonomous Space in Situ Sensor-web) [7]. OASIS merupakan sebuah kombinasi jaringan sensor di bumi dengan observasi satelit bumi miliknya NASA, untuk memantau aktifitas gunung api St. Helens di Amerika Serikat. Riset tetap berfokus pada usaha bagaimana membangun WSN yang robust untuk memperoleh rawdata sebanyak-banyaknya dengan real time secara kontinu dan kualitas serta konsistensi sinyal yang tinggi atau disebut juga high-fidelity, sehingga jaringan sensor dapat menggantikan data logger yang selama ini dipakai pada pemantauan tradisional menggunakan seismoter.

Implementasi sistem OASIS dilakukan di gunung St. Helens pada Oktober 2008 [5]. Lima stasiun berhasil disebar di kawah gunung api dengan diturunkan dari udara. Node sink yang telah dipasang modem Freewave berjarak 2 mil dari gateway yang terletak di JRO (Johnston Ridge Observatory). Server MOXA di gateway relay data ke sensorWeb yang ada di WSU Vancouver, yang berjarak 50 mil dari gateway. Sistem ini berhasil mengirimkan data jaringan sensor ke sensorWeb sebesar $91.7 \%$ dan selama 1.5 bulan. Uptime keseluruhan node jaringan mencapai 93.8\%.

Implementasi sistem OASIS yang ke-2 dilakukan pada Juli 2009, dengan menurunkan dari udara 13 stasion di kawah dan di sisi sekitar gunung St. Helens [6]. Konfigurasi sistem jaringan didesain multihop, sink node diletakkan di JRO dan dihubungkan ke gateway menggunakan koneksi serial. Server MOXA DE304 me-relay data ke server WSUV melalui link microwave dengan jarak 50 mil.

Tujuan utama dari implementasi WSN sistem OASIS adalah membangun data logger menggantikan data logger yang biasanya menjadi kendala utama pada sistem pemantauan gunung api tradisional. Untuk mencapai ini, dikembangkan perangkat keras, perangkat lunak, protokol, dan mekanisme-mekanisme sehingga sistem pemantauan gunung api mencapai high-fidelity yang real time, sistem dapat dikonfigurasi secara remote dan jaringan sensor berjalan secara robust dengan tingkat yang tinggi.

Desain dan pengembangan WSN di Gunung Tungurahua [1] dan Gunung Reventandor [2,3] maupun di Gunung St. Helens [4-7] dengan proyek OASIS merupakan penerapan WSN untuk pemantauan gunung api yang menciptakan beberapa desain algoritma, sebagai usaha untuk meningkatkan resolusi data yang dikirim ke base station. Begitu juga dengan penerapan WSN pada proyek DORSIVA[12] yang membangun sebuah remote sensing untuk memantau emisi gas dari Gunung Etna di Swedia, penerapan WSN [13] dengan tujuan untuk meningkatkan efisiensi energi dari node-node sensor dibandingkan dengan [1], dan penerapan WSN untuk memantau gunung api Cotopaxi di Ekuador [14] yang menggunakan wavelet transform untuk menentukan empat (4) macam kejadian yang terkait dengan gunung api. Semuanya masih berfokus pada penggunaan WSN untuk menangkap raw-data gempa vulkanik sebanyak-banyaknya dengan high-fidelity dan transmisi ke base station yang terus menerus secara real time. Di base station kemudian dilakukan proses analisis terhadap data gempa. Sehingga pengembangan seluruhnya diarahkan pada isu-isu yang terkait dengan sensing atau sampling sinyal yang berkualitas, jaringan sensor dan komunikasi yang sangat efisien, 
reliable, robust, dan cepat. Dalam hal ini WSN diterapkan sebagai pengganti instrumen pemantauan gunung api yang tradisional, yang mahal dan penyebarannya terbatas.

Sejauh ini, WSN untuk pemantauan aktifitas gunung api didesain dan dikembangkan untuk pengumpulan raw-data yang high-resolution, kontinu dan real time. Berbeda dengan sebelumnya, Rui Tan, dkk pada [8,10], dan Guojin Liu, dkk pada [9] melakukan pengembangan WSN untuk pemantauan aktifitas gunung api yang real time, in-situ, dan long-lived. Khususnya, kedua riset ini membangun algoritma pemrosesan sinyal innetwork untuk mendeteksi gempa vulkanik dan menentukan onset time dari gelombang primary $(P$-wave) yang biasa muncul pada saat terjadi kejadian gempa, tanpa transmisi raw-data ke base station.

Pengembangan WSN untuk deteksi gempa vulkanik di $[8,10]$ dilakukan dengan membangun algoritma deteksi didasarkan pada algoritma pemrosesan sinyal collaborative. Algoritma deteksi berjalan pada setiap sensor dan di base station. Sensor dan base station bekerja sama untuk mencapai kriteria kualitas sensing. Setiap sensor menangkap sinyal seismik. Base station memilih sekelompok sensor yang informatif didasarkan pada energi sinyal yang ditangkap oleh masing-masing sensor dan skalanya dikirimkan ke base station. Masing-masing sensor terpilih menghitung spektrum frekuensi sinyal dengan Fast Fourier Transform (FFT). Berdasarkan fitur energi sinyal dan spektrum frekuensi, sensor membuat keputusan deteksi ada tidak adanya gempa. Hasil keputusan deteksi lokal, dikirimkan ke base station untuk diambil keputusan akhir, ada tidaknya gempa, dengan fusion.

Gelombang seismik vulkanik secara umum dapat diklasifikasikan sebagai gelombang $\mathrm{P}$ (P-wave) dan gelombang S ( $S$-wave). Sistem ini $[8,10]$ menggunakan accelerometer yang low-cost dari Silicon Design, tipe 1221J-002, yang hanya responsif terhadap gelombang $\mathrm{P}(P$-wave). Spektrum frekuensi dan energi sinyal dari sinyal yang diterima oleh sensor diharapkan dapat menjadi fitur yang handal untuk mendeteksi gempa vulkanik menggunakan accelerometer yang low-cost ini. Kedua fitur diperhitungkan secara bersama oleh model multi-scale Bayesian yang dibangun pada sistem ini. Berdasarkan model Bayesian multi-scale, didesain detektor Bayesian di setiap sensor. Detektor akan membuat keputusan berdasarkan pada skala energi dan vektor fitur frekuensi. Sensor membuat keputusan antara hipotesis ada gempa dan tidak ada gempa, yang kemudian di-fuse di base station untuk meningkatan kualitas keputusan.

Di base station dilakukan fusing terhadap keputusan lokal dari sensor. Namun karena perbedaan performa sensing setiap sensor berbeda, disebabkan dinamika dan lokasi dari gempa vulkanik, perlu memilih sejumlah sensor yang memiliki kualitas sinyal terbaik untuk mencapai performa sistem deteksi yang maksimum. Pemilihan sensor, yang dianggap sebagai persoalan optimisasi, menggunakan strategi divide and conquer, yaitu dengan memilih $n$ sensor dari total $N$ sensor di jaringan. Untuk skema fusion, digunakan model fusion keputusan, yang biasa digunakan untuk WSN, yaitu equal gain combining (EGC) yang melakukan fusing keputusan lokal yang diambil oleh sensor dengan bobot yang sama $[8,10]$.

Algoritma-algoritma pada sistem deteksi ini telah diimplementasi dalam sistem operasi TinyOS 2.1.0 dengan platform TelosB sebanyak 24 mote dan percobaan dilakukan di 
laboratorium $[8,10]$. Percobaan ini didasarkan pada data yang dikumpulkan pada proyek OASIS [4], yang diambil selama 5.5 bulan dan terdiri dari sebanyak 128 segmen yang dipilih secara manual dan setiap segmen berdurasi 10 menit. Percobaan juga dilakukan dengan simulasi, untuk menghitung performa deteksi, di simulator TOSSIM.

Pada percobaan testbed di laboratorium, dibuat 2 topologi jaringan one-hop yang terdiri dari 12 node TelosB mote dan jaringan 3-hop yang terdiri dari 24 TelosB mote. Evaluasi performa terhadap percobaan ini menunjukkan false alarm/missing rate yang mendekati nol (0), delay deteksi kurang dari 1 detik, sementara energi berkurang sampai 6 kali dibandingkan dengan pendekatan data koleksi sebelumnya $[8,10]$.

Penerapan WSN berikutnya adalah menentukan timing gempa vulkanik tanpa transmisi raw-data seismik ke base station. Penentuan timing, dengan picking fase gelombang $\mathrm{P}$, biasanya dilakukan di bidang seismologi, dengan mengindentifikasi perubahan karakteristik sinyal seperti energi, frekuensi dan krakteristik model auto-regresif [9]. Fase gelombang $\mathrm{P}$ memberikan informasi yang penting bagi aplikasi pemantauan gunung api secara khusus untuk estimasi hiposenter gempa dan tomografi seismik.

Desain algoritma penentuan timing gempa vulkanik pada [9] untuk picking $P$-phase, dilakukan dengan pemrosesan sinyal in-network. Arsitektur jaringan WSN dibentuk secara hirarki dimana terdiri dari sensor dengan sumber daya terbatas dan koordinator dengan kapasitas pemrosesan dan energi baterai yang lebih besar. Pada implementasinya, platform TelosB digunakan sebagai sensor dan Imote2 digunakan sebagai koordinator. Secara prinsip jaringan didesain ke dalam satu atau lebih cluster, terdiri dari sejumlah sensor dan sebuah koordinator sebagai cluster head.

Dengan arsitektur jaringan seperti di atas, sejumlah algoritma dibangun dan berjalan di koordinator dan berhubungan dengan sensor, yang bekerjasama untuk mencapai tujuan penentuan timing gempa vulkanik.

Evaluasi terhadap performa penentuan timing gempa vulkanik di atas dilakukan dengan percobaan testbed dan simulasi, berdasarkan data riil yang dikumpulkan dari 12 node pada proyek OASIS [4]. Onset time dari setiap gempa dideteksi menggunakan pendekatan Bayesian [8]. Pendekatan ini mencapai keakuratan dari picking sementara hanya $16 \%$ dari data sensor yang ditransmisikan [9].

\section{HASIL DAN PEMBAHASAN}

Penerapan WSN untuk pemantauan gunung api, berdasarkan survei yang dilakukan, dapat dibagi ke dalam dua arah pengembangan yaitu penerapan WSN dengan arah pengembangan menggantikan jaringan seismik yang biasa digunakan pada stasiun pemantau baik fungsi sensing maupun fungsi data logger, sementara fungsi analisis bagian terpisah dari WSN, dan kedua, ke arah pengembangan algoritma yang memanfaatkan WSN bukan hanya sekedar melakukan fungsi sensing, tetapi juga fungsi analisis atau pengolahan data yang di-capture oleh WSN, menjadi informasi yang bernilai, berupa keputusan dan disampaikan ke pemakai akhir. 
Untuk arah pengembangan yang kedua, beberapa algoritma telah dikembangkan, seperti yang tertera pada Tabel 1 .

Tabel 1. Rangkuman model/algoritma yang digunakan

\begin{tabular}{|c|c|c|}
\hline Aplikasi & $\begin{array}{c}\text { Komponen Desain } \\
\text { Sistem }\end{array}$ & Algoritma/Model dan Penjelasan \\
\hline \multirow{4}{*}{$\begin{array}{l}\text { Volcanic } \\
\text { Earthquake } \\
\text { Detection[8, } \\
10]\end{array}$} & Ekstraksi Fitur & Fast Fourier Transform \\
\hline & Detektor Lokal & $\begin{array}{l}\text { Berdasarkan model Bayesian multi-scale, } \\
\text { keputusan diambil dengan pengujian } \\
\text { hipotesis statistik } H_{0} \text { dan } H p \text { terhadap ada } \\
\text { tidak adanya gempa }\end{array}$ \\
\hline & $\begin{array}{l}\text { Seleksi sensor secara } \\
\text { dinamik, untuk fusion } \\
\text { keputusan }\end{array}$ & $\begin{array}{l}\text { Berdasarkan strategi Divide and Conquer, } \\
\text { untuk memilih sensor yang informatif } \\
\text { berdasarkan sinyal energi yang diterima oleh } \\
\text { sensor. }\end{array}$ \\
\hline & Decision Fusion & $\begin{array}{l}\text { Berdasarkan model skema fusion, decision } \\
\text { fusion yaitu Equal Gain Combining (EGC), } \\
\text { yang fuse keputusan lokal dari sensor } \\
\text { dengan bobot yang sama }\end{array}$ \\
\hline \multirow{5}{*}{$\begin{array}{l}\text { Volcanic } \\
\text { Earthquake } \\
\text { Timing } \\
\text { [9] }\end{array}$} & $\begin{array}{l}\text { Sparsify of the signal } \\
\text { representation }\end{array}$ & $\begin{array}{l}\text { Discrete Wavelet transform (DWT) } \\
\text { berdasarkan wavelet Daubechies }\end{array}$ \\
\hline & $\begin{array}{l}\text { Picking P-phase awal di } \\
\text { sensor }\end{array}$ & $\begin{array}{l}\text { Lightweigth preliminary P-phase picking } \\
\text { algorithm }\end{array}$ \\
\hline & $\begin{array}{l}\text { Seleksi sensor untuk } \\
\text { timing gempa }\end{array}$ & Algoritma Nelder-Mead \\
\hline & $\begin{array}{l}\text { Kompresi sinyal dari } \\
\text { sensor terpilih }\end{array}$ & Berdasarkan Compressive Sampling (CS) \\
\hline & $\begin{array}{l}\text { Rekonstruksi sinyal oleh } \\
\text { koordinator dan picking } \\
\text { P-phase }\end{array}$ & $\begin{array}{l}\text { Algoritma picking Auto Regressive-Akaike } \\
\text { Information Criterion (AR-AIC) }\end{array}$ \\
\hline
\end{tabular}

\section{SIMPULAN}

Riset dan implementasi WSN untuk pemantauan aktifitas gunung api sampai sekarang memiliki dua arah atau tujuan. Pertama, pengembangan ke arah mendapatkan raw-data dari WSN dan mengirimkannya ke base station dengan high-resolution, high-fidelity, kontinu dan dalam waktu nyata, yang kedua, pengembangan tidak dengan mengirimkan raw-data ke base station tetapi melakukan pemrosesan di jaringan (in-network processing) untuk mendapatkan informasi yang penting dari lingkungan atau area pemantauan. Algoritma yang dikembangkan untuk mencapai tujuan pertama berfokus pada isu-isu pengembangan jaringan dan komunikasi di WSN. Sementara untuk tujuan yang kedua mengembangkan model dan algoritma seperti model Bayesian multi-scale, strategi divide and conquer, algoritma berbasis fusion, algoritma Nelder-Mead, penerapan compressive sampling, dan lain-lain yang dilakukan in-network.

\section{REFERENSI}

[1] Allen, GW., Johnson, J., Ruiz, M., Lees, J., dan Welsh, M. 2005. Monitoring volcanic eruptions with a wireless sensor network. Proceeedings of the Second 
European Workshop on Wireless Sensor Networks. Istanbul, Turkey, January 31 - February 2, 2005.

[2] Allen, GW., Lorincz, K., Welsh, M., Marcillo, O., Johnson, J., Ruiz, M. dan Lees, J. 2006. Deploying a Wireless Sensor Network on an Active Volcano. IEEE Internet Computing. Vol. 10(2): 18-25.

[3] Allen, GW., Lorincz K., Johnson, J., Lees, J., Welsh, M. 2006. Fidelity and Yield in a Volcano Monitoring Sensor Network. Proceedings of the 7th symposium on Operating systems design and implementation. Seattle, Washington, November 6-8, 2006.

[4] Song, W.Z., Huang, R., Xu, M., Ma, A., Shirazi, B., dan Lahusen, R. 2009. AirDropped Sensor Network for Real-Time High-Fidelity Volcano Monitoring. Proc. $7^{\text {th }}$ Int'l Conf. Mobile Systems, Applications, and Services (MobiSys). Kraków, Poland, June 22-25, 2009.

[5] Song, W.Z., Huang, R., Xu, M., Ma, A., Shirazi, B., dan Lahusen, R. 2010. Design and Deployment of Sensor Network for Real-Time High-Fidelity Volcano Monitoring. IEEE Transaction On Parallel and Distributed System. Vol. 21(11): 1658-1674.

[6] Huang, R., Song, W.Z., Xu, M., Peterson, N., Shirazi, B., dan Lahusen, R. 2012. Real-World Sensor Network for Long-Term Volcano Monitoring: Design and Findings. Parallel and Distributed Systems, IEEE Transactions. Vol. 23(2): 321329

[7] Peterson, N., Anusuya, R.L., Shirazi,, B., Song, W.Z., Huang, R., Tran, D., Chien, S., dan Lahusen, R. 2009. Volcano Monitoring: A case study in Pervasive Computing. In: A.-E. Hassanien et al. (Editors). Pervasive Computing: Innovations in Intelligent Multimedia and Applications. Springer-Verlag. 201230.

[8] Tan, R., Xing, G., Chen, J., Song, W.-Z, Huang, R. 2010. Quality-driven Volcanic Earthquake Detection using Wireless Sensor Networks. IEEE $31^{\text {st }}$ Real-Time Systems Symposium (RTSS). San Diego, CA, Nov. 30-Dec. 3, 2010.

[9] Liu, G., Tan, R., Zhou, R., Xing, G., Song, W.-Z., Lees, J.M. 2013. Volcanic Earthquake Timing using Wireless Sensor Networks. IPSN'13. Information Processing in Sensor Network. Philadelphia, Pennsylvania, USA, April 8-11, 2013.

[10] Tan, R., Xing, G., Chen, J., Song, W.-Z., Huang, R. 2013. Fusion-based Volcanic Earthquake Detection and Timing in Wireless Sensor Networks. ACM Transactions on Sensor Networks. Vol. 9(2): 17.1-17.25.

[11] Rawat, P., Singh, K.D, Chaouchi, H., Bonnin, J.M. 2014. Wireless Sensor Networks: A survey on recent developments and potential synergies. Journal Supercomputing. Springer. 68(1): 1-48.

[12] Zhang, Y. 2005. Wireless Sensor Network for Volcano Monitoring. Master of Science Thesis.

[13] Varaprasad, G. 2009. Wireless Sensor Network for Volcano Environment. SIGBED Review. Vol. 6(3)

[14] Lara, R., Caamaño, A., Zennaro, M., Rojo-Alvarez, J.L. 2012. Towards a New Volcano Monitoring System Using Wireless Sensor Networks. 
[15] Pratomo, I. 2006. Klasifikasi gunung api aktif Indonesia, studi kasus dari beberapa letusan gunung api dalam sejarah. Jurnal Geologi Indonesia. Vol. 1(4): 209-227.

[16] McNuttt, S.R., Rymer, H., Stix, J. 2000. Synthesis of Volcano Monitoring. In Encyclopedia of Volcanoes. Academic Press.

[17] USGS. 2006. Volcano and Earthquake Monitoring Plan for the Yellowstone Volcano Observatory, 2006-2015. Scientific Investigation Report. P.H Stauffer (editor).

[18] McNutt, S.R. 2000. Seismic Monitoring. In Encyclopedia of Volcanoes. Academic Press.

[19] R.I. Tilling. 2008. The critical role of volcano monitoring in risk reduction. $A d v$. Geosciences. Vol.14(3): 3-11. 